\title{
Give Me Equity or Give Me Death - The Role of Competition and Compensation in BUILDING SILICON VALLEY
}

\author{
RICHARD A. BOOTH
}

Why is Silicon Valley in California and not in Massachusetts? Route 128 - the Boston Beltway was the established center of high technology long before Silicon Valley even had a name. ${ }^{1}$ As of 1965, there were three times as many people employed in the technology sector along Route 128 as there were in Silicon Valley. ${ }^{2}$ But by 1975, Silicon Valley had caught up and pulled slightly ahead. Since then, Silicon Valley has left Route 128 in the dust. Indeed, Route 128 is no longer even among the top five employers in the technology sector. ${ }^{3}$

So why did Silicon Valley rise while Route 128 fell? More precisely, why did Route 128 fail to capture the new business that gravitated to Silicon Valley? And why does it matter?

It matters because it may tell us something about how to foster growth and innovation or at least not to stifle it. Enough said. But is it likely that there is anything this saga can teach us that is worth knowing? Things happen. It may be that the rise of Silicon Valley was a random event. It had to happen somewhere. Maybe. But the existing concentration of talent would seem to have made Route 128 the likely locus. Thus, at the very least there must have been something about California that overcame the presumption in favor of Massachusetts and drew the talent away from where it was most concentrated. Or was there something about Massachusetts that drove the talent away?

\section{THE BUSINESS DistRict PHENOMENON}

There is something a bit odd about this question. Why should we expect business activity of a particular type to concentrate itself in some one place? In a competitive economy one would expect businesses to seek spaces - geographic and otherwise - that have not already been occupied by the competition. Why then would one expect the technology sector to gravitate to a specific location? One might think that technology companies would be more likely to fan out geographically in order to capture the best and brightest talent as well as to take advantage of other untapped economic resources.

Similarly, one might also expect talented engineers to distribute themselves geographically so as to take advantage (for example) of lower costs of living.

\footnotetext{
${ }^{1}$ See Ronald J. Gilson, The Legal Infrastructure of High Technology Industrial Districts: Silicon Valley, Route 128, and Covenants Not to Compete, 74 N.Y.U. L. REv. 575, 586-89 (1999). Much of the first section of this paper is based rather shamelessly on the Gilson piece. I recommend it highly. Indeed, the Gilson piece is so good that I could not put it down without reading it through to the very end. And that is high praise for a law review article. In any event, I take no credit for the research or analysis herein relating to the business district phenomenon or the (possible) role of California law in connection with the rise of Silicon Valley. On the other hand, I should note that I have long been fascinated by the paradox that urban areas seem to command more wealth than rural areas even though the competition for wealth would seem to be more intense in urban areas.

${ }^{2}$ It is probably more accurate to measure the success of an industrial district by looking to its balance of payments vis a vis other industrial districts. In other words, many of the concepts of foreign exchange may be applied to cities and states and regions as well as to nation states. The difference, of course, is that one need not consider variations in the value of currencies since all transactions occur in uniform dollars. On the other hand, the cost of living can and does vary from one district to another. Gilson notes that in 1997 the San Jose area had foreign exports of \$29 billion while Boston area had foreign exports of $\$ 8.7$ billion. See id. at $587 \mathrm{n} .38$. These numbers include exports of all kinds of goods and services.

${ }^{3}$ See id. at 587.
} 
On the other hand, it is common for businesses to congregate with similar businesses. Residents of New York City know that certain businesses are likely to be found in certain areas of town. Art galleries and antique shops tend to locate along Madison Avenue above 57th Street. There is a flower district along Sixth Avenue around 23rd Street. The best Middle Eastern food is found on Atlantic Avenue in Brooklyn. And if you are in the market to furnish a nursery, the baby district is on Avenue A. Indeed, Madison Avenue is a synonym for the advertising business. And of course Wall Street is a synonym for the business of finance and to a lesser extent the practice of corporation law (though most Wall Street law firms have now moved to midtown). ${ }^{4}$

Why would these businesses choose to locate in proximity to each other rather than in a part of town where similar goods and services are less readily available? Why do they locate where the competition is most intense? (And while we are on the subject, why is the universe so lumpy?)

On one level, the answer is obvious. Why are there farmers markets? Because customers will know to go there to buy fresh produce and similar goods. The same idea explains the emergence of stock markets. But there is more to proximity than coordination and convenience. Geographic concentration also reduces the cost of gathering information and it reassures consumers. A business that locates in an area of intense competition effectively warrants its products and prices by making it easier for consumers to compare goods and services. ${ }^{5}$

Clearly this is a powerful business force. It is more expensive for a business to locate in a fashionable area than elsewhere. Indeed, the tendency of engineers and other techies to flock to Silicon Valley resulted in raising the cost of living there to one of the highest levels in the country. The benefits must somehow outweigh these costs.

The tendency of businesses (and markets) to gravitate to a focal point compounds the mystery of the rise of Silicon Valley and the fall of Route 128. If proximity is an advantage, it would seem that once a particular business has concentrated itself in a particular area it will be more difficult to establish a competing district. This phenomenon has been well documented in the financial markets where the establishment of a market for a stock or commodity in one place effectively eliminates the possibility of another market arising elsewhere. ${ }^{6}$ Indeed, in the commodities markets, commodities must be traded

\footnotetext{
${ }^{4}$ This process began in the 1970s. The first few firms to move encountered some criticism for doing so. One of the first major firms to move was Donovan Leisure Newton \& Irvine. As one of its partners, Truman Bidwell, quipped to a downtown critic, "The phones work dandy from up here."

${ }^{5}$ Here too, I borrow liberally from Gilson who also discusses the business district phenomenon, drawing on the late nineteenth century work of Alfred Marshall. See Gilson, supra note 1, at 580-86. See also ALFRED MARSHALL, PRINCIPLES OF ECONOMICS (Porcupine Press 1982) (1890). It may go without saying, but to ask the question why Silicon Valley became the force it is naturally raises the question why such activity should be concentrated in any one place. In other words, if Marshall did not exist, one would need to invent him. Similar forces explain the rise of cities themselves. Indeed, this would have been quite obvious to any peasant in the middle ages who would likely have thought of a city as synonymous with a market. Thus, one might well view the subject matter here as simply one case study in the much broader question why some cities (broadly defined) thrive while others decline. See Jon Gertner, Home Economics, N.Y.TIMES MAGAZINE, Mar. 5, 2006 at 94.

${ }^{6}$ See Richard A. Booth, The Uncertain Case for Regulating Program Trading, 1994 CoLuM. Bus. L. Rev. 1, 60 n.143. See also Laura Nyantung Beny, U.S. Secondary Stock Markets: A Survey of Current Regulatory and Structural Issues and a Reform Proposal to Enhance Competition, 2002 COLUM. BUS. L. REV. 399; Yakov Amihud \& Haim Mendelson, A New Approach to the Regulation of Trading Across Securities Markets, 71 N.Y.U. L. Rev. 1411 (1996) (discussing numerous studies indicating that price discovery occurs in one market even if
} 
where the first market arises. Parallel markets are not permitted. But none of the advantages of concentration discussed thus far seems especially pertinent to the technology sector. ${ }^{7}$

Ronald Gilson, building on the work of AnnaLee Saxenian, has offered an intriguing answer to the puzzle of why Silicon Valley evolved as it did even though Route 128 was in a better position to capture this growth. ${ }^{8}$ To put it simply, he suggests that one important factor in the rise of Silicon Valley is the fact that California law prohibits post-employment covenants not to compete, whereas

Massachusetts enforces them. ${ }^{9}$ To understate the obvious, enforcement of such agreements tends to bind an employee to the firm. It prevents employees with good ideas from striking out on their own. ${ }^{10}$ But that is not exactly Gilson's argument. Rather, he argues that enforcement of covenants not to compete prevent the spillover of so-called tacit knowledge-something like know-how-from one employer to another. ${ }^{11}$ As a result, a new business is precluded from—or at least retarded in-learning from existing businesses. $^{12}$

multiple markets exist) NASDAQ is a notable counterexample that tends to prove the point. Although the New York Stock Exchange was well established as the most active market for established US companies, NASDAQ began in the 1980s to capture a significant amount of the volume in NYSE stocks (despite rules that sought to prohibit NYSE member firms from trading elsewhere) and to retain listings of stocks (such as Microsoft and Intel) that historically would have sought listing on the NYSE. The inroads by NASDAQ were attributable to the rise of computer technology that obviated the need for a trading floor and a trading model that afforded quicker execution albeit without much chance for price improvement. To be sure, NASDAQ fell on hard times when the internet bubble burst. But it remains a serious competitor for the NYSE. The bottom line is that NASDAQ captured a significant share of trading volume because it offered a significantly different service from that offered by the NYSE.

${ }^{7}$ Analysis of the benefits of concentration may also offer insights about the nature of the corporation. Legal scholars have recently begun to look at the corporation as a form of organization that facilitates the accumulation of assets and that makes the withdrawal of those assets relatively difficult. See Margaret M. Blair \& Lynn A. Stout, A Team Production Theory of Corporate Law, 85 VA. L. REV. 247 (1999).

${ }^{8}$ See generally Gilson, supra note 1. See also Annalee SaXenian, Regional Advantage: Culture And COMPETITION IN SILICON VALLEY AND ROUTE 128 (1994).

${ }^{9}$ See Gilson, supra note 1, at 602-09.

${ }^{10}$ It may be nothing more than coincidence, but California follows a legal doctrine that limits to some extent the applicability of foreign corporation law to companies whose operations are located primarily in California. Under the so-called pseudo foreign corporation doctrine, the California courts may apply California law to companies incorporated in other states. See, e.g., Valtz v. Penta Inv. Corp., 139 Cal. Rptr. 2d 922, 925 (Cal. Ct. App. 1983) (public policy of California was to place no proper-purpose restriction on shareholders' right of inspection and the California courts had to enforce that policy despite corporation's Delaware incorporation). It may also be the case that California based companies choose Delaware law and use options as compensation in order to circumvent possibly more permissive rules that would be applied to California corporations as a matter of fiduciary duty under California law. In other words, the use of equity as compensation may be a way to capture the benefits of Delaware corporation law where California law might otherwise apply.

${ }^{11}$ See Gilson, supra note 1, at 594-602.

${ }^{12}$ As Gilson notes, Alan Hyde has proposed a slightly different hypothesis that west coast lawyers have subverted trade secret protection by rendering more liberal opinions as to the rights of firms to use the tacit knowledge of new employees even though it may violate the letter of trade secret law. Hyde's theory is that lawyers know that the former firm will not sue because they would suffer reputational consequences in an environment in which jobhopping is seen as a fundamental right and public good. Gilson rejects this explanation because it begs the question why job-hopping is protected in the first place. See Gilson, supra note 1, at 612-13. 
The rationale for enforcing a covenant not to compete is that it is the only practical way that a business can prevent an employee from disclosing trade secrets to competitors. The argument is that an employee who joins a competitor will inevitably disclose proprietary information to the competitor even if he makes a good faith effort to avoid doing so. ${ }^{13}$ To be sure, the cost of enforcement is that the employee is precluded from using his skills elsewhere. The question is: What is the greater cost? ${ }^{14}$

By enforcing covenants not to compete, Massachusetts law protected first generation businesses, but it retarded the growth of second generation businesses. California took a different path. And it turned out that the growth of second generation businesses was good for first generation businesses as well. In other words, the pot became bigger in California. ${ }^{15}$

This suggests that right-thinking businesses might voluntarily eschew employee non-compete agreements. But as Gilson points out, there is a serious collective action problem here. Even if the pot is bigger without such restrictions, an individual business will gain from adopting such restrictions on its employees. ${ }^{16}$ Indeed, it will gain even more if other businesses decline to adopt such restrictions. As in a cartel, the temptation is great for a business to break ranks. Thus, in the absence of a law against such restrictions, they will become universal - a classic market failure. ${ }^{17}$

That is Gilson's argument in a nutshell. He does not claim that it is a complete explanation for the success of Silicon Valley. And he does not claim the California approach is even beneficial for other business sectors. ${ }^{18}$ But in the end, Gilson thinks it is likely that California's prohibition of covenants not to compete has been an important factor in the success of Silicon Valley. I agree.

There is more to the story. At this point, I part company with Gilson. That is not to say that I disagree with his argument as far as it goes. Rather, I think the effects of California law are much more fundamental and pervasive than Gilson describes.

As noted above, the fact that California businesses in the aggregate gain from California law will not prevent individual businesses from seeking ways to circumvent the rules. Indeed, there have been several recent cases in which California businesses have sought to restrain former employees through the use of trade secret law in ways that could effectively impose a common law covenant not to compete. ${ }^{19}$ But that is another story.

${ }^{13}$ See Gilson, supra note 1, at 622-26.

${ }^{14}$ It is interesting that in many states non-compete agreements have been outlawed for attorneys but not for other professions and businesses. See Gelder Med. Group v Webber, 41 N.Y.2d 680, 683 (1977). See also Meehan v. Shaughnessy, 404 Mass. 419, 431 (1989).

${ }^{15}$ See Gilson, supra note 1, at 609.

${ }^{16}$ See id. at 609.

${ }^{17}$ On the other hand, businesses are free to move to another jurisdiction. See id. at 621.

${ }^{18}$ See id. at 627-29.

${ }^{19}$ See id. at 622-26. See also Tait Graves, Nonpublic Information and California Tort Law: A Proposal for Harmonizing California's Employee Mobility and Intellectual Property Regimes under the Uniform Trade Secrets Act, 10 UCLA J.L. \& TECH 1 (2006). 
There is a much more important device by which California firms can and do bind their employees. It is equity and the prospect of equity, which is to say, stock options. Although a firm cannot prevent an employee from jumping ship and joining a competing firm, a firm can deny future benefits to employees who leave..$^{20}$ In other words, a firm can bind its employees with golden handcuffs. Thus, it is my theory that the rise of equity compensation is to some extent explained by the prohibition of the traditional and obvious method of binding employees to the firm - the covenant not to compete. In turn, the widespread use of equity compensation in California may have revealed other benefits that led to even greater reliance on such forms of compensation so that ultimately they overtook cash in some settings. ${ }^{21}$

\section{THE VARIETIES OF EQUITY COMPENSATION}

Before digging into its subtler benefits, it is important to be clear that equity compensation may take several different forms, ranging from outright grants of stock to grants of stock options at the current market price. In other words, a company might pay an employee with stock that has some value at the time it is transferred. Or it might pay the employee with an option whose strike price is equal to the market price (or value) of the stock on the date of grant. ${ }^{22}$ Or the company may grant an option with a strike price that is higher than the market price (or value) of the stock. Or it may grant stock that vests only after some delay or if the market price meets certain targets. The possibilities are endless. Thus, for simplicity I will limit the discussion here to outright grants of stock and at-the-money options.

Technically speaking, stock options are not equity. Rather, a stock option is the right to buy equity at a specified price and on specified terms. But ultimately the value of a stock option depends on the value of the underlying equity. Thus, I use the term equity compensation generically here to refer to both stock and options.

Stock options are usually associated with publicly traded firms, so one might fairly question whether they can have any connection to the success of startup firms. After all, Silicon Valley is ultimately about the success of startups. But it is perfectly easy to devise an option plan or other system of equity compensation in a startup firm. Indeed, it is quite common in small firms for an employee to work (in part) for an ownership share. If the firm has no value, or the value is less than or equal to the claims of preferred stockholders (such as venture capitalists), then a share of common stock is essentially the same thing as an option. It has value only if the value of the firm increases.

\footnotetext{
${ }^{20}$ Or in appropriate cases, the firm may even permit an employee to retain the benefits of equity. But the burden is presumably on the employee to convince the employer in these cases. This too is a good thing because it induces employees to disclose their plans which may foster negotiation when it otherwise might not arise. To be sure, the employer may refuse to negotiate. In contrast, if the jurisdiction enforces non-compete agreements, the employer can refuse to negotiate and nonetheless bar an employee from competition. See Richard A. Booth, Limited Liability and the Efficient Allocation of Resources, 89 NW. U. L. REV. 140, 157 (1994) (arguing that the primary benefit of limited liability is to shift the burden to creditors to negotiate for additional security).

${ }^{21}$ To be sure, the skeptics seem to think that the primary motivation for compensating high level employees with options is that they fool the stockholders who pay attention only to earnings. It may be that some companies adopted generous stock option plans for this reason, even though it is quite unlikely that the market failed to take note of their dilutive effect. One of my goals in this piece is thus to offer an alternative explanation for the growth of options as compensation.

${ }^{22}$ Although such an option has positive value as a market instrument, it has value to the employee only if the value of the underlying stock increases.
} 
If the firm is established and its common stock has positive value but there is no market price because the firm is privately held, all that is necessary is that all agree on some method by which to value the firm and the terms under which an employee may cash out. Even that may not be necessary if the company goes public or is sold. To be sure, equity compensation is not as attractive if there is no market price to serve as an objective measure of value (whether in the interim or at cashout). Moreover, the need for an objective measure of value may induce companies to plan ahead for liquidity in order to make their compensation plan more attractive. And that in itself may be a subtle benefit of equity compensation.

If the company is publicly held, it is obviously quite easy to set up a stock option plan. The market price of the stock serves as a ready and objective measure of value. ${ }^{23}$

It is not really necessary here to get into the details of how one could or should structure a system of equity compensation and whether it should be based on options or equity. The point for the present is that it is possible to use equity as compensation in any business setting. ${ }^{24}$

Finally, I use the term employee very broadly to include everyone from the CEO down. Although equity compensation outside the technology sector is often limited to high level managers, it is quite common in the technology sector for most employees (or at least those that one might describe as professionals) to be so compensated. That itself may be due in part to the use of equity as a substitute for a covenant not to compete among California-based companies. Although it may go without saying, the prohibition against covenants not to compete is not a matter of corporation law. Rather, it applies to all employees based in California even if the corporation itself is a Delaware corporation. I use the terms cash-compensated employee and equity-compensated employee relatively to refer to employees who receive more or less of their compensation in cash and more or less of their compensation in some form of equity. Needless to say, there are infinite possible combinations of cash and equity not to mention a wide variety of forms that each might take. I make no claim to know how much equity compensation as a percentage of total compensation is necessary to trigger the changes in employee attitude that I discuss here.

\section{THE SIDE-BENEFITS OF EQUITY COMPENSATION}

Although equity compensation may have been born from the necessity of finding a way to bind employees to the firm in California, it turns out that it has significant side benefits.

\footnotetext{
${ }^{23}$ The use of stock options as compensation by large publicly traded companies has been criticized of late on various grounds. For one, critics have suggested that options induce management to take excessive risks in order to increase stock price rather than preserve existing value. Thus, it has been suggested that it would be preferable to use grants of stock as compensation. But it seems unlikely that options would induce a CEO to assume excessive risk given that the downside is to be fired and to lose both salary and incentive compensation. Moreover, it is not clear that stockholders-especially diversified stockholders—-prefer cautious management. Quite to the contrary, a diversified stockholder stands to gain if all companies seek to maximize stockholder value even if a few go bust trying. Thus, contrary to popular opinion, options are preferable to grants of stock in publicly traded companies. I suspect that one reason for the controversy about how best to compensate management is that the critics have failed to notice that in a small company, stock is more like an option than it is like stock in a big company, and that the popular image of the stockholder-entrepreneur as the prototypical long-term investor is a bit of a myth. In short, it can be difficult to distinguish between options and stock-especially in the context of equity compensation. That is one more reason to think more generically about equity compensation.

${ }^{24}$ The use of equity as compensation may have emerged from the primordial stew in small firms and then spread to big firms or vice versa. Or it may have emerged more or less simultaneously in both settings. Although it would be interesting to know exactly how equity compensation spread, it is sufficient for the moment simply to recognize that it may be used in businesses of all sizes.
} 
First and fairly obviously, incentives work better than penalties. ${ }^{25}$ Equity induces employees to work harder and to focus on how their efforts contribute to the success of the business. Although it is obviously an advantage here for the company to be publicly traded, equity may work just as well in smaller more focused companies where there is a clear connection between employee effort and the bottom line. The bigger the company and the more complex its operations, the more tenuous the connection between effort and reward and the greater the likelihood of free-riding by more employees.

In larger companies, the use of options as compensation may also induce voluntary breakups through spin-offs, split-ups, and other similar transactions. In a large company with diverse (and separable) lines of business, options may lose much of their allure because stock price depends on the performance of the business as a whole. Individual employees who work in a single line of business may resent the fact that their efforts contribute to the gains of those who work in other lines of business or they may be tempted to slack off and free ride on the efforts of others. Thus, it may be necessary to break up the business in order to make equity compensation meaningful and motivate employees. This in turn may explain the resistance by many larger and more established companies to the use of options. And it may explain why in such companies options tend to be limited to the CEO and a relatively small number of high level officers. In such a company, it may be more appropriate to use bonuses that can be tailored to the contributions of individual employees. ${ }^{26}$ It may seem a bit odd to think that facilitating compensation should drive fundamental changes in organizational structure. But the market also tends to respond favorably to such transactions because in general the market dislikes diversified companies. ${ }^{27}$ It is cheap and easy for investors to diversify, so they gain nothing from company level diversification for its own sake. ${ }^{28}$ Indeed, investors will tend to eschew such companies because they offer a package deal. Moreover, management is more likely to be well focused in a non-diversified company and is thus more likely to succeed - other things being equal. To paraphrase Charles Emerson Winchester: The market likes a company that does one thing, does it well, and then moves on. Finally, it so happens that in such a company it makes more sense to compensate more employees with equity and options.

Second and still fairly obviously, equity compensation saves cash for the startup firm. Although employees must still be paid something in cash, firms can compete for talent without offering more cash. They can offer more equity. Moreover, when options are exercised the company receives cash equal to the exercise price-a pretty good reason for even a startup company to use options rather than an outright grant of equity. Options also induce employees to save in anticipation of exercise and thus to save more than they otherwise might be inclined to save. That in turn creates a pool of local capital that becomes available for new businesses or the expansion of existing businesses. Although capital is obviously quite mobile, it stands to reason that the beneficiaries of equity compensation are at least somewhat more likely to invest locally in what (and whom) they know. ${ }^{29}$

\footnotetext{
${ }^{25}$ See Alan O. Sykes, The Boundaries of Vicarious Liability: An Economic Analysis of the Scope of Employment Rule and Related Legal Doctrines, 101 Harv. L. Rev. 563, 570 (1988).

${ }^{26}$ See Saul Levmore, Puzzling Stock Options and Compensation Norms, 149 U. PA. L. REV. 1901, 1905 (2001). In the alternative, a company may do a virtual spinoff by issuing tracking stock.

${ }^{27}$ See Richard A. Booth, Stockholders, Stakeholders, and Bagholders (How Investor Diversification Affects Fiduciary Duty), 53 Bus. LAw. 429, 435-36 (1998).

${ }^{28}$ This is not to say that investors cannot gain from strategic diversification at the company level (for example in order to offer a full line of products to a customer base that wants it) or from vertical or horizontal integration.

${ }^{29}$ See Randall Stross, It's Not Who You Know. It's Where You Are., N.Y. TIMES, Oct. 22, 2006, at 3.
} 
Third, using equity as compensation forces the company to seek and plan for liquidity. Although most smaller companies have a general idea that the goal is to sell out or go public, a company that uses equity as a significant portion of its compensation for many of its employees must have a plan and stick to it. And that again keeps management more focused. It is not clear that it is a good thing to grow companies for harvest like timber or cattle, but the practice has made Silicon Valley what it is. In other words, it may be that Route 128 has created more long term value with less Brownian Motion, but I doubt it. Value ultimately inheres in the ability to sell a commodity. ${ }^{30}$ Moreover, by focusing on an exit strategy, management will be more likely to grow the company in ways that appeal most to the market in order to maximize value upon exit. In contrast, if the need for exit is not writ in stone, management may be tempted to settle for a merely adequate return. ${ }^{31}$ If the culture of Silicon Valley is more conducive to maximizing value, it should hardly be surprising that Silicon Valley has dominated. ${ }^{32}$

Fourth, if equity is a significant portion of an employee's compensation, the employee will be forced to think hard about the prospects of the employer firm. Employees (and prospective employees) will vote with their feet. They will seek out jobs with firms that they see as most likely to succeed. A firm will need to convince employees—both prospective and current—of its business strategy and (perhaps more importantly) to adjust that strategy based on input from employees. ${ }^{33}$ Equity may also induce employees to jump ship if a business or product loses its promise. In other words, an employee who is paid significantly in equity is more likely to cut his losses and switch jobs than one who is compensated simply with cash. Although one might argue that it is not a good thing to encourage employees to be disloyal-particularly when a business is struggling-it is also arguable that it is a good thing for employees to vote with their feet if it hastens the demise of businesses with little promise. It

\footnotetext{
${ }^{30}$ See generally RoBert W. HAMILTON \& RICHARD A. BOOTH, BUSINESS BASICS FOR LAW STUDENTS $§ 7.3$ (2006). It is noteworthy that in the venture capital industry, valuation based on such techniques as discounted cash flow (DCF) is strongly disfavored. See Private Equity Industry Guidelines Group (PEIGG), U.S. Private Equity Valuations Guidelines, Sept. 2004, at 9, available at http://www.peigg.org/images/U.S._PE_Valuation_Guidelines_September_04.pdf. In contrast, DCF is clearly the preferred method of valuation under Delaware corporation law. See HAMILTON \& Booth, supra note 30 . The explanation for this discrepancy is that as a matter of corporation law, the issue of valuation generally arises in a situation in which there is no true sale and the plaintiff wants (or claims to want) to remain a stockholder in a going concern, while the goal of valuation in the venture capital industry is to estimate the price at which a company could actually be sold.
}

${ }^{31}$ To be sure, venture capital investors will also insist on a well-defined exit strategy. So if venture capital investors are involved, the company may be more likely to use of equity compensation generously. Although venture capital investors typically demand generous rates of return, they usually specify some amount that will suffice. And they get paid first. So in the end, the presence of venture capital investors is not a sufficient condition for heavy reliance on equity compensation.

${ }^{32}$ And the phenomenon is likely to be magnified over time by compounding.

33 This does not necessarily imply that one or a few firms will emerge as the most desirable employers or that a pecking order will evolve. Although that is a possibility, it depends to some extent on the nature of the industry. Equity compensation may be better suited to technology firms than other types of firms because of the wide array of products and their modular nature. It may not be as powerful in a simple manufacturing setting, which may explain why there is no Salad Shooter Valley. It is also possible that employees (and prospective employees) will have varying views about the prospects of various companies and their products. Other things being equal, individual employees will likely gravitate to a firm whose business and strategy is well understood and where it seems that the employee is likely to make the biggest contribution. There is no reason to think that all will see one or a few companies or products as the optimal object of their human capital. In other words, equity has the potential to induce better matching of employees to firms than other forms of compensation. 
means that resources are less likely to be wasted and better products are more likely to be produced sooner. ${ }^{34}$ To be sure, it is arguable that employees are likely to leave a sinking ship anyway. But it seems clear that at the margin a cash-compensated employee is more likely to remain on the job longer and to seek to preserve the job than is an equity-compensated employee. ${ }^{35}$ By the same token, equity compensation may encourage employees to stick with promising firms even though they may struggle financially for a few years. In other words, equity compensation likely induces employees to take the long-term view.

It is arguable that I have overstated the effect of California law on the rise of equity compensation. Although the advantages of equity compensation as outlined above are substantial, it is difficult to believe that options would come to pervade a local economy to such an extent that they would change its fundamental character. On the other hand, if a few firms offer options as a substantial part of their compensation package for many employees, it seems likely that all firms will be required to do so. As a result, startups and small firms will be compelled to offer equity and options even if they might not be inclined to do so anyway. For example, in the 1990s, it became common for law firms in Silicon Valley to accept options as part of the payment for their fees. Many law firms became quite wealthy as a result. And eventually many law firms insisted on options before they would agree to take on a new client firm. (This may also have led law firms to consider the prospects of potential client firms.) Again, options started out as a way for startups to save cash, but they became the norm.

In short, the fact that California law prohibits the enforcement of non-compete agreements may have triggered the use of equity compensation which then took on a life of its own much as chaos theory posits a butterfly effect. ${ }^{36}$

\footnotetext{
${ }^{34}$ Some legal scholars have argued that United States bankruptcy law is the single most important feature of the legal system that distinguishes it from that of other developed countries and that it accounts for much of the success of the American economy relative to other economies. In addition, I might argue that ready access to limited liability entities is an equally important feature of the United States legal system. But that is really only an extension (albeit an important one) of the point that liberal bankruptcy laws encourage growth. The ultimate point is that the system does not discourage entrepreneurs from throwing in the towel when it makes sense to do so. In the absence of limited liability, many entrepreneurs might be likely to invest good money after bad in an effort to avoid loss rather than generate gain. To be sure, there is a bit of a chicken and egg problem with this view. Free access to limited liability works only if one is confident that over the long haul the business will generate more gain than loss. See Production Resources Group v. NCT Corporation, 863 A.2d 772, 787 n.47 (Del. Ch. 2004) (citing Mark J. Roe, The Shareholder Wealth Maximization Norm and Industrial Organization, 149 U. Pa. L. Rev. 2063, 2065 (2001)). This is not to say that the laws relating to personal bankruptcy ought to be equally liberal. Indeed there is no correlate to limited liability as a matter of personal status. Rather, limited liability is all about being in business and seeking profit. Equity compensation enhances these forces.

${ }^{35}$ Indeed, the average tenure of an employee in Silicon Valley is 31 months compared to the national average of 42 months. See Virginia Postrel, In Silicon Valley, Job Hopping Contributes to Innovation, N.Y. TIMES, Dec. 1, 2005, at $\mathrm{C} 4: 1$.

${ }^{36}$ I do not mean to suggest that California law relating to non-compete agreements is the single or even primary explanation for the rise of equity compensation. Indeed, there were many other factors at work. See Richard A. Booth, Executive Compensation, Corporate Governance, and the Partner-Manager, 2005 U. Ill. L. Rev. 269, 27376. Several legal scholars have suggested that the primary (if not sole) cause was the 1993 tax act, which eliminated the deductibility of compensation in excess of $\$ 1$ million per individual employee unless such compensation is incentive-based. See Jerry Markham, Regulating Excessive Executive Compensation - Why Bother?, 2 J. BuS. TECH. L. (2007) (forthcoming).
} 
In addition, the widespread use of equity compensation in California may also have had secondary effects that are difficult to quantify or even describe. It may have induced a more cooperative attitude in general. It may explain to some extent the emergence of the distinction between east coast deals and west coast deals. ${ }^{37}$ It seems likely that it accounts for the visceral reaction that Silicon Valley firms (most notably Intel) had to the proposal of changes in accounting rules that require the expensing of stock options. Although I happen to agree that expensing is a bad idea, I do not think that in the end it makes much difference to the market. Thus, I suspect that much of the reaction stemmed from a more fundamental objection to the idea that the grant of options should be seen as equivalent to cash compensation rather than as a deal by which an employee can work in part for an ownership share and participate in the gain from his efforts. In any event, there can be little doubt that there is a different attitude in Silicon Valley about equity compensation.

\section{THE MASSACHUSETTS EXPERIENCE}

The experience in Massachusetts has been quite different. Massachusetts is widely regarded as the leading jurisdiction for innovative legal thinking in connection with closely held corporations. Judging by the number of cases appearing in the leading law school casebooks, the Massachusetts courts appear to have spent more energy developing a body of law tailored to closely held corporations than any other jurisdiction in the United States. But that is not necessarily a good thing. Indeed, one might argue that excessive litigation is a sign that something is wrong.

Most of the litigation in Massachusetts has been about the sharing of returns between majority and minority stockholders in successful corporations. This suggests that equity participation is quite common in closely held Massachusetts corporations. But it also suggests failure to plan for liquidity. In other words, the Massachusetts experience suggests that successful Massachusetts corporations are less likely to seek a public market for their shares. Indeed, Massachusetts law effectively defines a closely held corporation as one with no public market for its shares. ${ }^{38}$ If equity is seen as an important part of compensation by employees from the outset, it seems likely that they will want to know about how the company plans to provide liquidity for its shares. And employees of successful companies are likely to pressure the firm to go public or sell out as early as possible. ${ }^{39}$ In fairness, Massachusetts law relating to employee competition with the employer corporation is rather permissive. For example, under Massachusetts law the corporation must show that it had a specific or express expectation relating to a business opportunity in order to show that an officer or director usurped the opportunity in violation of his fiduciary duty to the corporation. ${ }^{40}$ To be sure, this may be pure coincidence. And one must be careful not to make too strong a claim for a causal connection. But California appears to have been relatively free of such litigation.

\footnotetext{
${ }^{37}$ See Gilson, supra note 1, at 612. The east coast / west coast distinction is more than an impressionistic generalization about different styles of lawyering. The NVCA model term sheet contains several alternative provisions depending on whether the deal in question is an east coast deal or a west coast deal. National Venture Capital Association, Term Sheet, Jan. 2004, at 9 n. 12, available at http://www.nvca.org/model_documents/Term_Sheet.DOC.

${ }^{38}$ See Donahue v. Rodd Electrotype Co., 367 Mass. 578, 586 (Mass. 1975). But see Nixon v. Blackwell, 626 A.2d 1366, 1379-81 (Del. 1993) (refusing to create special rules applicable in closely held corporations).

${ }^{39}$ Coincidentally, the leading California case holds that a majority stockholder may not establish a market for his own shares while denying that market to minority stockholders. See Jones v. H.F. Ahmanson \& Co., 460 P.2d 464, 476 (Cal. 1969).

${ }^{40}$ See, e.g., Lincoln Stores v. Grant, 34 N.E.2d 704, 707 (Mass. 1941).
} 


\section{EQUITY COMPENSATION AS A SUBSTITUTE FOR LAW}

The foregoing suggests one final rationale for equity compensation. Equity compensation may be an efficient substitute for more intrusive forms of dispute resolution such as fiduciary duty. The term fiduciary duty is inherently vague. Indeed, some scholars have argued that its inherent vagueness is one of the strengths of fiduciary duty. Be that as it may, it is difficult and expensive to litigate a fiduciary duty case. And one can never be confident that it is cost effective to do so. ${ }^{41}$

The potential benefits of equity compensation can be seen more clearly if one analyzes the potential for disputes in more detail. Generally speaking, there are two types of dispute that may arise in this context.

First, if the company is successful, the dispute is likely to be about sharing the wealth. Equity compensation is likely to prevent such disputes because the parties have effectively bargained about the matter in advance.

Second, a controversy sounding in fiduciary duty may also arise if a company fails. For example, it may be that the departure of one or a few key employees to a competitor causes a promising company to fail. In such a case, the failed company (or its owners) may seek recovery from former employees. Of course, it may be that the company was doomed to fail in the first place, in which case the disgruntled owners may use fiduciary duty as a weapon of aggression to seek a share of the wealth generated by former employees. Needless to say, it will often be difficult to determine why a business fails. But here too reliance on equity compensation may tend to reduce litigation somewhat. The fact that an employee who jumps ship must presumably abandon his equity when he changes jobs lends credence to his decision. As I have argued elsewhere, many cases raising duty of loyalty issues seem to turn on whether the defendant fiduciary assumed genuine risk in striking out on his own. ${ }^{42}$ Other things being equal, it would seem that an employee who abandons his equity compensation will be more likely to meet that burden and that employers will be less likely to sue except in relatively strong cases. Thus, employers will be less likely to use fiduciary duty for revenge or as an anticompetitive weapon. In short, it seems likely that there will be less litigation in the context of failed ventures as well as successful ventures. ${ }^{43}$

${ }^{41}$ It is ironic that such disputes are litigated in courts of equity. It should go without saying at this point, but equity compensation may also serve as a partial substitute for the protections of intellectual property law. It goes without saying because that is essentially the point of this essay, namely, that equity compensation emerged at least in part because California law forbids the enforcement of non-compete agreements, which I would classify as a form of IP law albeit contractual. Indeed, one could argue that fiduciary duty itself is a form of IP law or at least that there is a continuum of law protecting such intangible goods as knowledge, ideas, and opportunities that extends from formal intellectual property to common law doctrines relating to trade secrets and unfair competition and ultimately to fiduciary duty.

${ }^{42}$ For example, in Meinhard v. Salmon, 164 N.E. 545 (N.Y. 1928), a case that involved the appropriation by one partner of the opportunity to participate in the renewal of a lease, the fact that the venture in question was wellestablished and profitable seems to be important as does the fact that the other partner sued promptly upon discovering the facts. In contrast, in Lincoln Stores, a case that involved the establishment of a competing department store by employees of an established department store, the established firm neglected to sue the former employees for more than a year. See Lincoln Stores, supra note 41, at 707.

${ }^{43}$ Failed ventures are less of a worry anyway because they are likely to end up in bankruptcy court whether or not there are allegations of breach of fiduciary duty on the part of departing employees. 


\section{THE NEED FOR FURTHER RESEARCH}

Much of what I suggest here is bald-faced speculation. There is little that I can prove right now about the causal connection between California law prohibiting the enforcement of employee agreements not to compete and the rise of equity compensation or the connection between the latter and the beneficial secondary effects that equity compensation may induce. So the question is whether there is any evidence that stock options do in fact work as I say they might in California. There are many ways that these assertions may be tested empirically.

1. Are there differences state to state in the amount (percent) of equity held by employees? Do the terms differ state to state? For example, is it more common for employees to buy into an employer company in Massachusetts as opposed to receiving an outright grant as would seem more common in California?

2. How did the use of equity compensation evolve in terms of company size? Did the practice begin in smaller firms and spread to larger firms or vice versa? Or did the practice arise independently for different reasons?

3. Does the use of equity compensation differ industry to industry either in aggregate amount or in the details? Is there any pattern as to the use of options versus stock? Are California firms more likely to commit to an exit strategy? Is there any difference in the number of firms that go public or are sold? Is there any correlation between equity compensation and going public or sale? That is, are companies with significant employee equity more likely to go public or be sold at an earlier stage? It seems quite likely that the presence of venture capital investors will be correlated with earlier exit and commitments thereto, but that is a fact that should be verified. A subtler question is whether venture capital-backed firms are more likely to use equity as compensation.

4. Is there any difference in the valuation methods used among companies that do not commit to an exit strategy?

5. Are California companies more likely to go public or be sold at an earlier stage than Massachusetts companies? Are spin-offs and other divisive reorganizations more common among California companies than they are among Massachusetts companies?

6. Are salaries lower among employees of California-based technology companies than they are among Massachusetts-based companies? If there are such differences, do they prevent companies from expanding into other geographic areas (in order to maintain equity employee to employee), and does such geographical bias lead successful businesses to expand more rapidly in their home territory? Is there a tendency among employees who receive equity compensation to reinvest available funds in local companies rather than companies located elsewhere? Are California investors more tolerant of equity compensation than other investors? What are the practices of various service industries in using equity as compensation?

7. Is there any difference state to state for the reasons that employees change jobs? Are they more likely to leave a failing business sooner? Are they more likely to move to a more promising job even though their current prospects are good? Are employees who switch jobs in California or Massachusetts more or less likely to retain or be permitted to retain equity in the company they leave?

8. Do fiduciary duty cases involving technology companies arise more often in California or Massachusetts? Do such cases arise more often in the context of successful or failed companies and does the incidence differ between California and Massachusetts? Does the law relating to piercing the 
corporate veil differ state to state? Are the courts of California more forgiving when it comes to business failures?

In each case, it is also important to know how practice evolved over time. For example, it is possible that equity compensation arose as a substitute for non-compete agreements in California but spread to Massachusetts because of other perceived advantages.

One complicating factor is that California law applies based on the location of the operation while Massachusetts law applies if the company is incorporated in Massachusetts. This suggests a further question: Does the choice of the state of incorporation matter? Is there any difference state to state in the choice of domestic law versus Delaware law? ${ }^{44}$

Generally speaking, I am somewhat skeptical about the use of empirical research as a way to determine what legal rules should be. In many cases, the data is skewed by the influence of legal rules themselves. For example, I doubt that there is much to be learned from empirical research about when courts do and do not find a breach of fiduciary duty because the behavior of fiduciaries is likely to be affected by their perception of what the law requires. The same goes for cases involving veil piercing and other situations in which individual liability may obtain, such as under the law of fraudulent transfers. But the kind of empirical research that I suggest here is somewhat different. The question is not so much what the law should be in any absolute sense as it is how legal rules operate in combination with each other and in differing economic settings. Thus, the kind of research $\mathrm{I}$ have in mind is more akin to the work of Mark Roe and the SSLV group who have considered the symbiotic relationship of the common law and strong markets. ${ }^{45}$ In other words, the question is not really a normative one about what the law should be. Rather, the question is ultimately a descriptive one about what the law really is.

\footnotetext{
${ }^{44}$ Gilson notes that California law does not seem to prevent companies from locating there when they have a choice. See Gilson, supra note 1, at 622.

${ }^{45}$ See Gordon Smith in this symposium.
} 